\title{
Infiltrating Bladder Urothelial Carcinoma Associated with Urethral Carcinoma
}

National Cancer Institute

\section{Source}

National Cancer Institute. Infiltrating Bladder Urothelial Carcinoma Associated with

Urethral Carcinoma. NCI Thesaurus. Code C115966.

Infiltrating transitional cell carcinoma of the bladder which is associated with the presence of in situ or infiltrating urethral carcinoma. 